\title{
African Sexual Extraversion and Getting into Bed with Robert Mapplethorpe
}

If the erotic spreads over social life much farther than the telos of reproduction would suggest, how do we come to grips with this situation? Georges Bataille provides, I believe, a beginning:

Eroticism, it may be said, is assenting to life up to the point of death. Strictly speaking, this is not a definition, but I think the formula gives the meaning of eroticism better than any other. If a precise definition were called for, the starting-point would certainly have to be sexual reproductive activity, of which eroticism is a special form. Sexual reproductive activity is common to sexual animals and men, but only men appear to have turned their sexual activity into erotic activity. Eroticism, unlike simple sexual activity, is a psychological quest independent of the natural goal: reproduction and the desire for children. (Bataille [1957] 1986, II)

Bataille notices that all human societies, as opposed to animal ones, set taboos around two areas of life-sex and death. Sex is typically carried out in private. And we dispose of the dead. Our closest animal relatives do neither. These two observations are linked by Bataille. The erotic is a kind of death, a dissolution 
of personhood, a glimpse into the most fundamental religious experience of continuity. And the taboos around the erotic are not merely negative ones. "We can," Bataille writes, "even go as far as the absurd proposition: The taboo is there in order to be violated" (64).

From erotics, Bataille quickly jumps to some of the most fundamental aspects of religious experience, opining along the way, "In one sense, the Christian religion is possibly the least religious of them all [because of its relative anti-eroticism]" (32). We need not follow Bataille to all his positions to appreciate two points: (l) the erotic is not defined by the telos of reproduction, and (2) transgressions of sexual taboos are built into the very structure of the erotic. Unstable, the erotic changes over time. Forms of human sociality depend upon the erotic, and as forms of sociality vary, so do erotics.

With this framing in place, let me turn to Atlantic African forms of sociality. For some time, one of the most insightful theorists of African politics has been Jean-François Bayart ([1989] 1993, 2000). He has argued that African forms of relating rest upon patterns of what he calls "extraversion." Social actors, rather than deepening exploitation of their own dependents, build power by pursuing relationships of external dependenceall the while using the cunning and guile of the prototypical trickster in West African folktales to turn apparent subordination into power, at least locally.

Some scholars have questioned the explanatory weight that Bayart attempts to place on this syndrome. And to an anthropologist like me, having first done fieldwork in East and South Africa, it seems to capture a pattern perhaps not continental, but particularly West African. Indeed, one wonders whether this orientation to the social world was not some adaptation to the 
upset and upheaval caused by the Atlantic slave trade. However that may be, "extraversion" is a striking idea that unifies much disparate work, from studies of so-called scams to the novels of Francis Nyamnjoh (20II). And in the present context, it uncannily captures the case at hand: young Atlantic African men on gay Internet dating sites looking for European lovers. What was their "sexual orientation" (Ahmed 2006)? We might answer, after Bayart: extraversion.

West African vodun carvings appear to provide an usually striking illustration of this argument. According to Suzanne Blier's African interlocutors, the statue's penis is associated with trickery. "The penis is associated with Legba, a deity of trickery, communication with the gods and sexual potency. Erect phalluses distinguish this latter deity's shrines and ritual objects" (1995, I47-48). Power and potency, sexual and otherwise, depend upon communication and sometimes trickery.

It should be clear by now that the neighborhood my friend had landed in was quite different from its surrounding cultural context. Inside the ghetto, African relationships with gay Europeans were more or less approved. This was not easy in some cases and certainly not public. But such relationships enabled a kind of continuity in Bataille's terms; I discovered that African male-European male sexual relationships had existed at least as far back as the fathers of the young men I interviewed and probably farther. Before the Internet, men in the ghetto had placed personal ads in European and North American gay publications by mail in the I980s. As little as a decade earlier (Meeker 2006), any number of changes in communicative infrastructure-for example, what the post office would accept as mail-had laid the necessary groundwork for how sexual minorities would make contact. Atlantic African men from the ghetto were soon 
"linked in," even before the Internet would once again transform sexual connectivities.

One father and son worked in tandem to entice Europeans. Another young man I ran into was named for his father's European lover: Angus (to change the name but to keep its Scots flavor). One particularly successful man of around fifty, who had a computer and a modem at home, and who had had a German lover when he was younger, offered himself as a gobetween for the young men of the neighborhood. "They are all my kids," he said. He offered advice and guidance about European gays, the unstated assumption being that he would receive gifts from the boys when the latter received monies from their new friends. Same-sex sex was a communal project in the ghetto, one that was subject to competition and jealousy as well as help and sharing of information. It was not uncommon for young men to attempt to take away the European lovers of their neighbors.

African wives sometimes protested. One apparently stood outside her house and shouted to the neighbors, "You know what my husband is doing in there? He's fucking that white man." But the neighbors quickly sat her down and asked her just how she thought that she and her children were being supported. She needed to respect that or go back to her parents. This kind of social pressure created an ambiguous and fluid social situation in which one's self could be expanded to the degree that he (usually but not always males) could manipulate the hold of fetishes over others.

If African men's erotic inclinations were focused on extraversion, what about the white Europeans, North Americans, and Australians who found their way to the ghetto? What was their "sexual orientation"? 
One German gay man I interviewed said, "I am attracted to black men. Not only that," he said with a laugh, "my black friends tell me I'm attracted to ugly black men." An Australian man pointed out that there were very few black men in his country. He had had an aboriginal boyfriend early on, but the last four of his boyfriends had all been African, all from the ghetto. From what I could tell, most of the white men in the ghetto had a fetish for black men. "I can't explain it," one said. "There is just something about the texture of black skin."

As I have pointed out, racial fetishes remain controversial, especially to racial minorities in North America. Racial fetishes often focus precisely on those physical aspects targeted by racists themselves: what Fanon called "epidermalization" being perhaps the central one. But no African I interviewed in the ghetto interpreted white attractions as racism. Just the opposite-Africans seemed pleased to celebrate such attractions, which, after all, represented something of a reversal of typical colonial patterns. One recounted his white lover's delight and surprise when the lover first saw his penis. In addition, many Africans interpreted white enthrallments as the result of the power of the ritual charms they had procured. In other words, white attractions to blacks were typically read as a confirmation of African power.

If anyone were exploiting anyone-and this is not the idiom I would choose in this situation-Africans, it was my impression, typically enjoyed the upper hand, in Africa. That they themselves viewed the situation in this light would seem to be corroborated by the fact that they treated Europeans as "wives" (as I shall explain in the conclusion). That is not to say, of course, that Europeans did not enjoy more "power" in some global sense. They had white skin and passports and relative wealth. They could go home-but, of course, their fetishes kept pulling them back to Africa. 
That pull was, it is clear, embedded, even if with a different valence, in some of the same phantasms as white racism. Not long after the earliest years of European expansion, a white-isjust-right story proved remarkably enduring over the centuries, one that linked race globally with gender. To simplify (racism is already a simplification, of course), Africans, both male and female, were thought to have too much body and not enough mind. Consequently, both African men and African women were masculinized in relation to whites. That made African men supermales and African women incompletely feminine, compared to whites. Conversely, Asians were thought to have too much mind and not enough body. Both male and female Asians were feminized in relation to whites. That made Asian men incompletely masculine but Asian women superfemales. ${ }^{1}$

This Lévi-Straussian pattern of oppositions created African males and Asian females as spectacular figures of libidinal interest. As early as the seventeenth century, European travelers began commenting on the sexual equipment of African men, their "large Propagators" (Hyam 1990, 204). And Asian women became the symmetrical opposite: refined, submissive, and beguilingly beautiful Madam Butterflies, the subject of Italian operas.

Writing of the eighteenth century, Bleys (1995, 90) contends: “The Enlightenment debate on other races' natural status ... was very clearly marked by an ascription of sexual qualities. This was shown perhaps most prominently in the ascription of 'feminine' characteristics to the people of America, Asia and the Pacific, while Sub-Saharan Africans and Arabs were most commonly accredited with a rather exaggerated and 'uncivilized' masculinity."

The point of whiteness was that it was "just right," not unlike the story of the three bears' porridge-too hot, too cold, just 
right. In other words, the structure of racism is not always a simple hierarchy with whites "on top" (Paul n.d.). It can represent a more complex notion of proper balance.

The sexual attractions to African males and Asian females that arose out of these investments were not symmetrical, of course. To be attracted to an African man was potentially to participate in the fantasy of being overpowered, whereas being attracted to an Asian female was potentially related to domination itself.

The irony of these racial fantasies, in relation to black men in the United States and Europe, is that in reality, few had any real power at all. They were themselves abjected in a system of racial capitalism. So how did white racial fetishes form? Almost no research has been done on this question, past Mumford (1997) on the North American example of the rg2os. My speculation, following Bataille's discussion of transgression, is that black men become intensely erotic figures (for some white men and women) when they appear to reverse and challenge the actual system of racial domination.

Photographs of black bodies accomplishing such reversals (such as, say, the famous black power salute from the 1968 Olympics) may have played a role in creating racial fetishes. Before the pervasiveness of photographic images, the imprinting of fetishes upon social actors depended upon unmediated seeing (sometimes complemented by the more evolutionary ancient senses of smell and touch). Afterward, the camera not only conveyed fetishes but also may have played a role in propagating them. ${ }^{2}$ Such a focus on the mediation of sexual fixations is not new. Lawrence Stone (1992) proposed that flagellation was first spread to the middle classes in England when engraved pornography became widely available in the early eighteenth century. 
Compared to etching, photography has perhaps an elective affinity with race in that it can capture skin tones so subtly.

Whether these speculations have any value, by the end of the 1970s, racial fetishes were common in North American gay communities. Black men attracted to white men were known as "snow queens," white men attracted to black men, "dinge queens." White men attracted to Asians were called "rice queens," Asians attracted to whites, "potato queens." By the r980s, bars and social organizations based on these fetishes existed in most gay communities in the United States (see M. Smith 1983). It was not unusual for the interracial organizations based on these attractions to take the lead in attacking the evident racism of the gay community itself.

For the quintessential example of a white man with a fetish for black men, let me turn to Robert Mapplethorpe. His photograph Man in Polyester Suit is often called his masterpiece, a designation that works in more than one sense. When he first confronted it, the black gay critic Kobena Mercer attacked the photograph as racist, as did others. Later he significantly modulated his position. I would suggest that the photograph be read as a depiction not of black men per se but of white fascinations with them, Mapplethorpe's in particular (Morrisroe 1995, 234).

According to Luc Sante $(1995,47)$, Mapplethorpe's photographs "do not show sex as much as they enact it, locating the act in the exchange between the photographer and whoever looks at his work. The viewer is pressed into service as proxy partner, top and bottom at once. The reactions of Jesse Helms and his ilk would no doubt have given Mapplethorpe satisfaction-their horror only proves that he succeeded in getting them into bed with him."

Man in Polyester Suit is, of course, focused on the black phallus. The punctum of the photograph, in Roland Barthes's terms, 
is the engorged and uncircumsized black member with a slight glistening at the tip. ${ }^{4}$ The work is, in its entirety, devoted to the contrast between the luminosity of the black skin and the flatness of the polyester suit, an industrially produced material not unlike other fetishized materials like rubber or vinyl.

It is easy to be reductionistic about the black phallus. Take the case of Johnny. There were, after all, many black gay men in Oakland. He hardly needed to go to Africa to find one. There was clearly something else, some supplement that drew white gay men to the African ghetto. This was, I believe, the difference that Africa offered by the beginning of the twenty-first century. The heady days of black liberation in the United States - and of the Black Panthers, closer to Johnny's previous home in Oakland-were decisively over. Africa furnished another frontier. And postcolonial Africa, compared to the United States, was no longer structured by racial domination, even if white privilege remained (Pierre 20I3). That meant that white men's fetishes for black men did not so immediately raise the recall, as it did in the United States, of blacks' quotidian experiences of white racism.

In a sense, white gay men in Johnny's new home were something like anthropologists of an earlier day (see Grinker 2000 for the example of Colin Turnbull). They were attracted by cultural difference. They were attentive to structures of world power that marginalized Africans. And they often took up local projects that resembled those of activist development agentssetting up libraries for local children, microfinancing for local small enterprises, and so-called appropriate technology transfers. In some real sense, it was the overdetermined "meaningfulness" of this situation that kept whites coming back. Africa provided a kind of stakes for living that was missing at home, even if most whites only visited for a few months out of the year. 